\title{
三菱美唄炭礦における探炭機械化の推移亚びに成果
}

境

武

夫

The Developement of the Mechanical Mining Colliery at Bibai

Takeo SAKAI

At the Bibai Mine steel props were used for the first time in early spring of 1950 . It was in January, 1951 when the "Kappe" mining started there. Since then "Kappe", steel props, cutters, loaders and conveyors have been greatly improved. The use of those powerful machines based on the increased length faces and the concentration of working places has caused a higher productivity.

\begin{tabular}{l|c|c|c} 
& Prod/t/month & Output/face & Output Whole Workers/t/day \\
\hline Apr.' 50 & 45,600 & 2.60 & 0.46 \\
Apr.' 53 & 101,400 & 5.13 & 0.92 \\
Productivity raised in\% & 222 & 197 & 208
\end{tabular}

Because of the location of the pit mouths, mining conditions ore very much complicated at the Bibai Mine. As a result all sorts of scientific research are required for the various conditions. The mining engineers there are exerting themselves day and night for finding out better ways of mining and adoption advanced machines. The following is the report of the development of the mechanical mining of the mine especially in the gently sloping seams.

\section{I 機械化の概要及び推移}

当所においては昭和25年初春鉄杜孛使用し，更に昭和

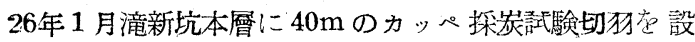
定，2力月間にわたり試験岀行つた後 26 年 2 月潼一坑四

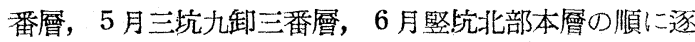
次カッペ化し，現在楥傾斜算については全払のカッペ化

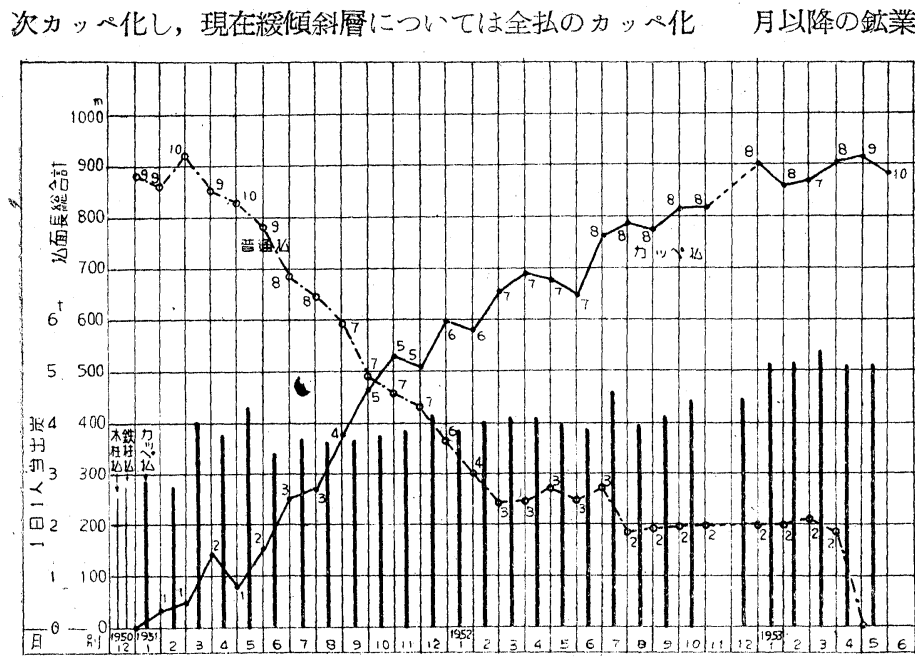

第 1 図䌅傾斜払機械化推移図。

\section{* 三渂鉱業株式会社美唄鉱業所}

登終了した。当所に执いて泣坑口分散し，稼行炭層も多 い関係上区域別層別に非常に條件が異なるため，これ等 の條件を科学的に究明し，てれそれに適応する探龙方式 と機器の探用に不断の努力を傾注し, 完全機械化の達成 に努好てる。以下当所に扮ける緩傾斜層探炭機械化の 推移並びに成果について報告したいと思う。昭和 25 年 1 月以降の鉣業所の機械化の推移京機械化推移図(第1図) に示す。

\section{II 機械化の成果}

\section{1. 出㞸の推移}

出炭の推移については生座推移図 （第２四）!示方如く全捖 1 日当出炭 は，機械採炭実施前は3000 $\mathrm{t}$ 前後であ つた况，機械化とともに逐次上舁し28 年3月に扎てて 4500 t 范示してい る。緩傾斜拙出炭はカッペ探炭以前は 1 日当 2000 七であつたが, 逐次上舁 し28年3月には2850 tである。この 中カッベ払は 26 年 3 月開始当時は 200 t/日であつたが，機械化とともに逐 次上昇し 26 年 3 月には $2535 \mathrm{t}$ 芫示 


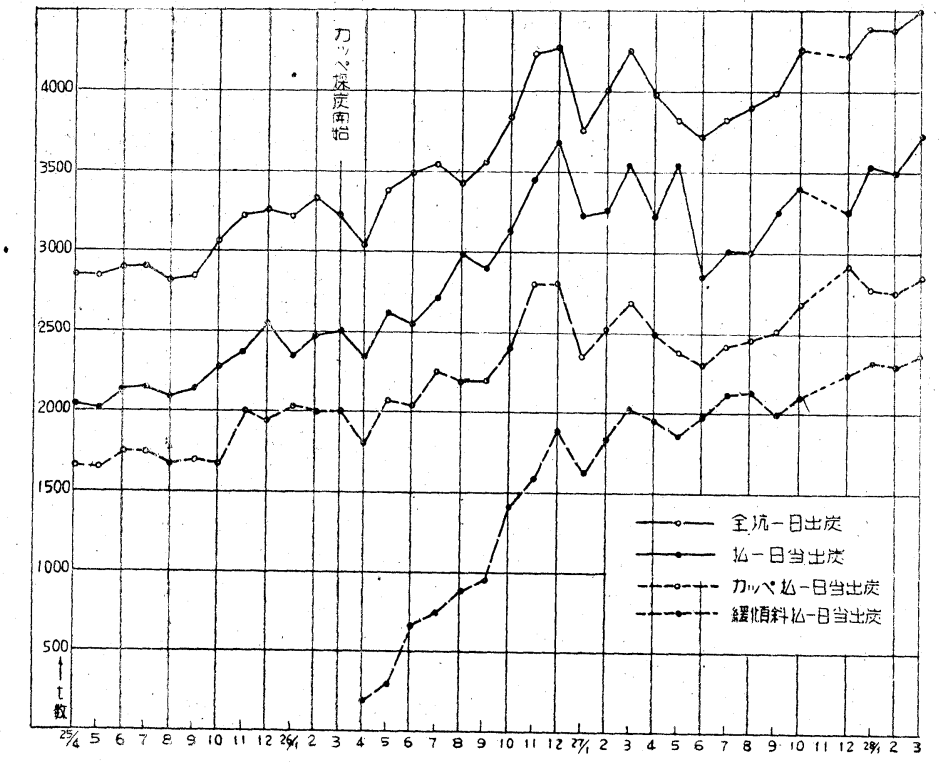

第 2 図緩倾斜払の生產推移闵

し, 坑木, 火薬, 電力之も第 3 図原単 位推移図に示す如く相当の減少を示し ている。坑別の綏傾斜層代表切旸につ いて, 鉄杜・木笠木, 鉄杜・カッペ使 用時の $\mathrm{t}$ 当直接費点比較すると。機械 化効果表（層別代表切犲）第 1 表に示 す如く38 55\%の経費節減を示してい る。

\section{III 使用機器の推移}

\section{1. 鋼 支“柱}

現在 9092 本の鋼支杜を使用してい るが, 月廃裹率は $5.1 \%$ \%示している。 第 4 目に示吉如 $く$, 鉄杜・木笠木当時 は 30〜35 $\mathrm{t}$ 耐圧のものであつたが， カッペ使用とともに逐次强度が要求せ られ50 $\mathrm{t}$ 耐圧に切替えられ，現在は7 $\mathrm{t}$ 耐圧のものを採用している。切旸の 盤圧降縮特性を調査してれぞれの特性

し，盖通执は315 七客出炭しているにすぎない。

\section{2. 能率の推移}

全矿夫 1 日当出炭は 25 年 4 月には $0.4 \mathrm{t}$ を示していた が，機峨化とともに逐次上昇し 28 年 3 月に打いて $0.809 \mathrm{t}$ 走している。緩傾斜払の本均能率は，機械化 推移図（第1図）に示古如く木杜払に打いては2.55屯， 銑杜木笠木当時は $2.70 \mathrm{t}$ 定示していたが，機械化によ り逐次上昇し，28年 3 月!扮いては $5.27 \mathrm{t}$ となり $207 \%$ と能率上昇老示している。

\section{3. 資材及び経費の推移}

$\mathrm{t}$ 当抗木, 火苴, 電力の使用量は穖械化とともに逐次 節減せられ，27 年度下期!こ挍いては 25 年度上期に比較

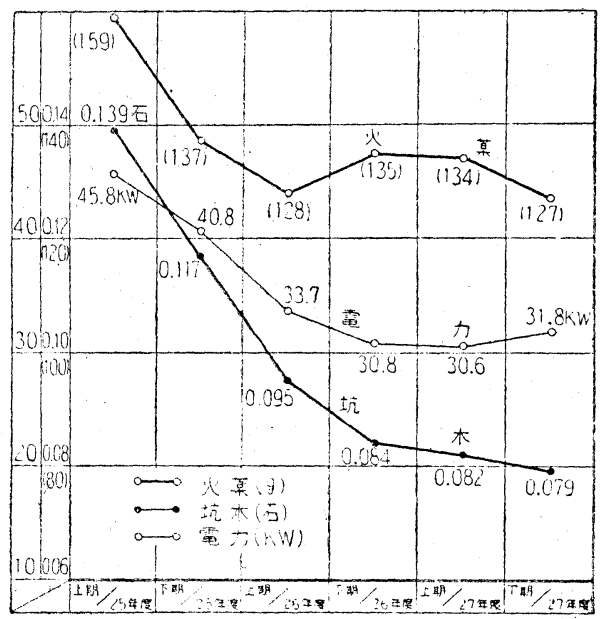

第3図原単位の推移図

( $\mathrm{t}$ 当の坑木, 火薬, 電力㹬用量) ・
に適広した鉄杜学探用し，同一型式同一製作所のものて 特性の一致したもの菠用する如く努力している。型式 については全面的に G. H. H. 型存探用して来たが，28

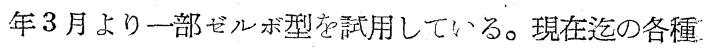
鉄杜总使用した結果結論ずけられることは，切犲に使用 する鉄杜特性としては降縮量少なく，高い盤圧を支持し 周期的荷重に対し逃げを有し，それぞれの盤圧降緛特性 に応し，同一の特性存もたしめるということであるが， 最近ゼルボ型も実用の域に達しつつあるので，当所とし

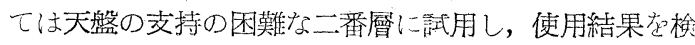
討の上各署に応じた特性の鉄杜の探用を計画している。 切犲喿作上必要なことはカッター，ローダー等の機械の 為の空間を䇟くするため, コッター芷短くすることと， 抗張力の大きい材質支使用し, 重量定晫減し, 立杜回收 の操作を円滑にしたい。

\section{2. カッ ペ}

当所は現在 8019 本のカッペ等使用し，月廃裹率 5.6 \%を圭している。カッペは愹接カッペより出発したので あるが，当初のものは材質，構造ともに不良で愹接部分 の强度少なく, 本体强度15 20 t, 接手部强度 $5 \sim 10 \mathrm{t}$ であり，扗使用の結果著しい破損莡きたした。その後抗 張力, 肉厚の增加, 各部構造の改良により逐次强度を向 上し, 本体强度 20２5 $\mathrm{t}$, 接手部强度 10１3 $\mathrm{t}$ に達し たが，整形のため材質の疲学著しく熔接カッペの寿命は 1.5年程度に過ぎないので，27年7月より鍛造カッへにに逐 次切替え省行つているが，本体强度 $30 \sim 35 \mathrm{t}$, 接手部 强度 $15 \mathrm{t}$ で使用結果良好で, 月廃裹率 $0.8 \%$ 程度であ る。堅抗西部本硧払は天盤軟弱でカッペの操作困難であ 
第1表 機栈化效果表（層別代表切狗）

\begin{tabular}{|c|c|c|c|c|c|c|}
\hline 切狗名称 & & & & 昭和 26 年 3 月 $\left(\begin{array}{cc}\text { 鉄 } & \text { 桂 } \\
\text { 笠木 }\end{array}\right)$ & 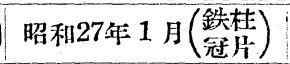 & 昭和28年 2 月 $\left(\begin{array}{l}\text { 鉄桂 } \\
\text { 耑片 }\end{array}\right)$ \\
\hline \multirow{6}{*}{$\begin{array}{l}\text { 三 } \\
\text { 西本㸝三番層 }\end{array}$} & & $\begin{array}{r}\text { 炭 } \\
\text { 亳 } \\
\text { 变 } \\
\text { 長 } \\
\end{array}$ & $\begin{array}{l}\mathrm{t} / \text { 日 } \\
\mathrm{t} / \mathrm{\beta} / \boldsymbol{1} \\
\mathrm{m} \\
\mathrm{m} \\
\%\end{array}$ & $\begin{array}{c}140 \\
44 \\
3.18 \\
1.1 \\
85 \\
100\end{array}$ & $\begin{array}{l}185 \\
45 \\
4.11 \\
1.0 \\
85 \\
87.0\end{array}$ & $\begin{array}{c}321 \\
38 \\
5.88 \\
1.0 \\
100 \\
62.2\end{array}$ \\
\hline & \multirow{4}{*}{$\begin{array}{l}\text { 使 } \\
\text { 用 } \\
\text { 機 } \\
\text { 械 }\end{array}$} & \multirow{2}{*}{ コンベャ } & 払 & \multirow{2}{*}{$\begin{array}{l}\mathrm{V} \text { 型コンベヤ } \\
\text { ベルトコンベヤ }\end{array}$} & \multirow{2}{*}{ 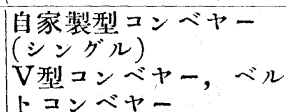 } & $\begin{array}{l}\text { 香家製H型コンベャー } \\
(\text { (ジグ) }\end{array}$ \\
\hline & & & 片盤 & & & |゙゙ルトコンム゙ヤー \\
\hline & & & $\mid \begin{array}{c}\text { カッター } \\
\text { ローダ- } \\
\text { ローピック } \\
\text { ドリル }\end{array}$ & 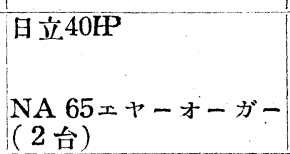 & $\begin{array}{l}\text { 日立 } 40 \mathrm{P} \\
\mathrm{NA}-65 x+ー オ ー カ ゙ \\
-(2 \text { 台 })\end{array}$ & 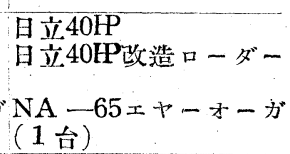 \\
\hline & & & $\begin{array}{ll}\text { 鉄 桂 } \\
\text { 冠 }\end{array}$ & $1.0 \mathrm{~m}(433$ 本 $)$ & $\begin{array}{l}1.0 \mathrm{~m}(418 \text { 本 }) \\
1.2 \mathrm{~m}(338 \text { 本 })\end{array}$ & $\begin{array}{l}1.0 \mathrm{~m}(545 \text { 本 }) \\
1.2 \mathrm{~m}(619 \text { 本 })\end{array}$ \\
\hline & 勢 & $\begin{array}{l}\text { 能率上䊬 } \\
\text { 経費瓝 }\end{array}$ & $\%$ & $\begin{array}{l}100 \\
100\end{array}$ & $\begin{array}{r}129.5 \\
87.0\end{array}$ & $\begin{array}{r}184.2 \\
62.2\end{array}$ \\
\hline \multirow{6}{*}{ 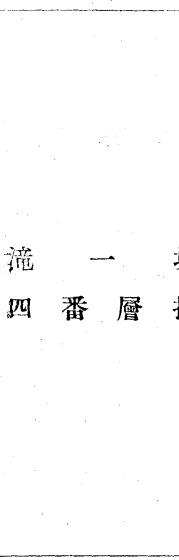 } & $\begin{array}{l}\text { 出 } \\
\text { 人 } \\
\text { 能 } \\
\text { 亗 } \\
\text { 面 } \\
\mathrm{t}\end{array}$ & $\begin{array}{r}\text { 炭 } \\
\text { 繂 } \\
\text { 爱 } \\
\text { 長 }\end{array}$ & $\begin{array}{l}\mathrm{t} / \text { 日 } \\
\text { 人 } \\
\mathrm{t} / \text { 日/人 } \\
\mathrm{m} \\
\mathrm{m} \\
\%\end{array}$ & $\begin{array}{c}200 \\
55 \\
3.63 \\
1.6 \\
73 \\
100\end{array}$ & $\begin{array}{c}291 \\
49 \\
5.99 \\
1.65 \\
88 \\
93.3\end{array}$ & $\begin{array}{c}604 \\
82 \\
7.36 \\
1.65 \\
141 \\
60.0\end{array}$ \\
\hline & & 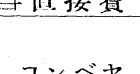 & $\begin{array}{l}\% \\
\text { 払 }\end{array}$ & V型コンベャ一 & $\begin{array}{l}\text { 息家製型コンベャー } \\
\text { ジングル }\end{array}$ & $\begin{array}{l}\text { 西重H型コシべャー } \\
(\text { ダブル) }\end{array}$ \\
\hline & 伎 & & 片 盤 & 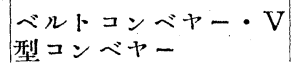 & ベルトコンベヤー・回 & 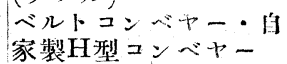 \\
\hline & $\begin{array}{l}\text { 用 } \\
\text { 機 } \\
\text { 械. }\end{array}$ & & $\mid \begin{array}{c}\text { カッター } \\
\text { ローダー } \\
\text { ールピック } \\
\text { ドリル }\end{array}$ & $\begin{array}{l}\text { 日立 } 40 \mathrm{H} \\
\mathrm{NA}-65 x+\text { - } \\
-(2 \text { 台 })\end{array}$ & 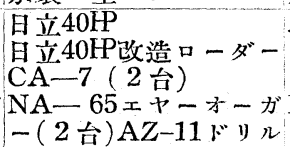 & 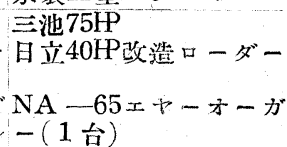 \\
\hline & & & $\begin{array}{ll}\text { 鉄 㭙 } \\
\text { 年 }\end{array}$ & $1.8 \mathrm{~m}(536$ 本 $)$ & $\begin{array}{l}1.8 \mathrm{~m}(403 \text { 本 }) \\
1.2 \mathrm{~m}(399 \text { 本 })\end{array}$ & $\begin{array}{l}1.8 \mathrm{~m}(823 \text { 本 }) \\
1.2 \mathrm{~m}(750 \text { 本 })\end{array}$ \\
\hline & 効 & $\begin{array}{l}\text { 能率上暴 } \\
\text { 経䩀聥娍 }\end{array}$ & $\%$ & $\begin{array}{l}100 \\
100\end{array}$ & $\begin{array}{c}165 \\
93.3\end{array}$ & $\begin{array}{l}203 \\
60.0\end{array}$ \\
\hline \multirow{6}{*}{ 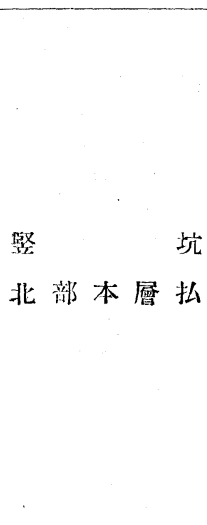 } & $\begin{array}{l}\text { 出 } \\
\text { 能 } \\
\text { 奤 }\end{array}$ & 弈 & $\begin{array}{l}\mathrm{t} / \text { 日 } \\
\text { 人 } \\
\mathrm{t} / \mathrm{\theta} / 人 \\
\mathrm{~m} \\
\mathrm{~m}\end{array}$ & $\begin{array}{l}270 \\
120 \\
2.24 \\
2.2 \\
90\end{array}$ & $\begin{array}{l}290 \\
94 \\
3.09 \\
2.1 \\
90\end{array}$ & $\begin{array}{l}437 \\
70 \\
6.24 \\
1.9 \\
122\end{array}$ \\
\hline & $\mathrm{t}$ & 当谁接費 & $\%$ & 100 & 98.9 & 44.3 \\
\hline & \multirow{3}{*}{$\begin{array}{l}\text { 使 } \\
\text { 用 } \\
\text { 機 } \\
\text { 械 }\end{array}$} & コンぶヤ & 片 & $\begin{array}{l}\text { 自家製H型コンベヤー } \\
\text { ベルトコンベヤー } \\
(4 \text { 台 })\end{array}$ & 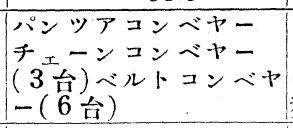 & 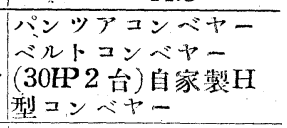 \\
\hline & & & 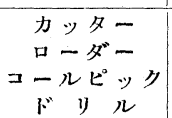 & $\mathrm{CA}-7$ 32台 & $\mathrm{CA}-7$ 25台 & $\mathrm{CA}-7$ 26台 \\
\hline & & & 鉄禁片 & $2.2 \mathrm{~m}(638$ 本 $)$ & $\begin{array}{l}2.2 \mathrm{~m}(669 \text { 本 }) \\
1.2 \mathrm{~m}(640 \text { 本 })\end{array}$ & $\begin{array}{l}2.2 \mathrm{~m}(689 \text { 本 }) \\
1.2 \mathrm{~m}(654 \text { 本 })\end{array}$ \\
\hline & 效 & $\begin{array}{l}\text { 能率上舁 } \\
\text { 経費源娍 }\end{array}$ & $\%$ & $\begin{array}{l}100 \\
100\end{array}$ & $\begin{array}{c}138 \\
98.9\end{array}$ & $\begin{array}{l}279 \\
44.3\end{array}$ \\
\hline
\end{tabular}

り，山文も大きいため軽合金カッパを使用している。本 体, 接手部, 强度とも良好であるが，ねぢれを生じ熱好 理が困難で，場所における整形不能の難点がある。將来 全面的に鍛造シュ一型式を探用の予定であるが，天盤不 良箇所に対しては軽合金シューカッペの採用を持続した い。長さは $1.2 \mathrm{~m}$ 考全面的に採用しているが，盤圧の少

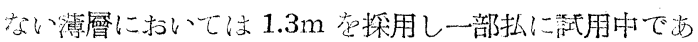
る。

\section{3. フェースコンベヤ}

現在H型シングル 3 台, H型ダブル日立 3 台, 西重 1 台，パンツァー3台在使用している。当初H型シングル チェーンコン心゙中主として便用していた放，チェーン 切断, モーターの過負荷, トラフ高さ等の問題があり, H型ダブルに逐次切替えている。パンッァーは断層の多 い㹂抗北部本層払に抢いて 2 年近く使用し，15万 $\mathrm{t}$ 以上 運搬しているが故障少なく，トラフチェーン等の整耗 


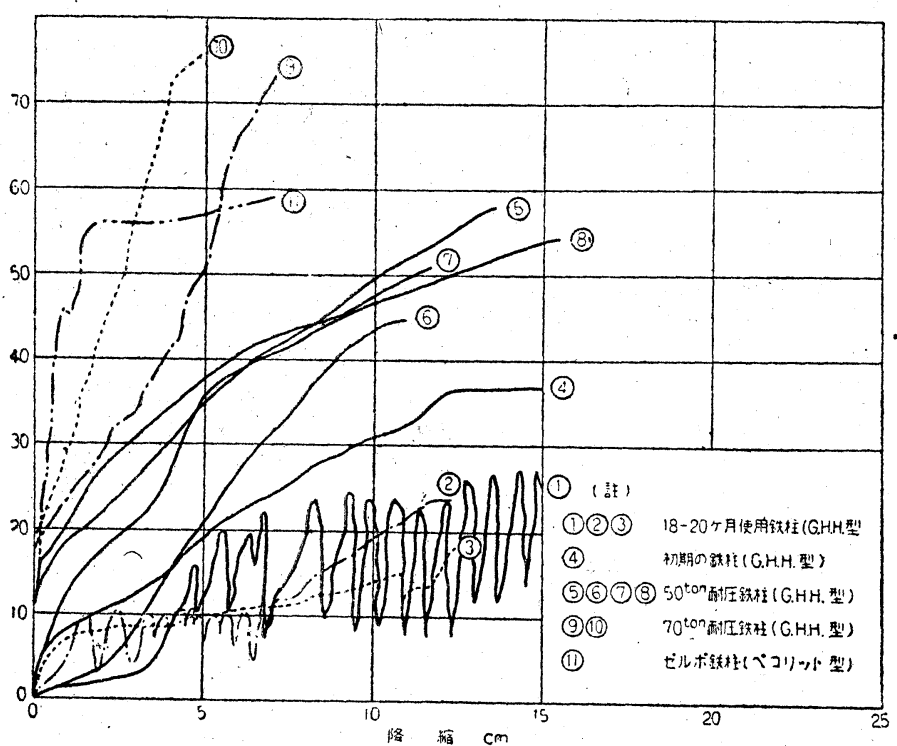

第4図荷重降縮線図

払作業の $40 \%$ 苍しるる積込作業炎解決 することが機峨化の最も重要な要素であ り，如何なるローダーを使用するかが， カッベ探炭成否の鍵であると云つても過 言でない。当所に抢いてはカッペ探炭開 始に先立ちフェースローダーの研究に着 手サリバンC.L.E. 一2 型改造による チェーン迴転式のフェースローダーを試 作，払使用の上種々改良を加え，ピルッ 付ローダー(C.L.-2), 二段ジブローダ - (C.L. 3), 老完成し, 滝一抗四番尿三 抗三番層に使用し高能率をあげている。 この型式はュンベヤの上に在つて二殷ジ ブで発破後の石炭をコンベヤーに積込 み, コンベヤ高さの残炭の処理に人員を 要するため, 下盤上にあつてコンべャに ベンドジブをもつて積込むCL-4\%試作 し，現在三坑第四卸二番痟において試用 少なく払コン心゙として絕詨的な優秀さを示している。 現在の性能々り將来 $200 \mathrm{~m}$ 以上の延長も可能である。パ ンッァーと互換性の市可磨ニン心゙わについては検討中 である。

\section{4. コールカッター}

現在日立40HP 5 台, 日立50Hシングルジブカッター 1 台，ダブルジブカッター1台，三池50Hダブルジブカッ ター1台，三池75Pダブルジブカッターー1台，アイコフ $40 \mathrm{P}$ ダブルジブカッター4台定使用している。機械化探 炭実施前においてはサリバン C.L.E-2 型, $30 \mathrm{P}$ ，日立40Hシングルジブカッタ 一趸主として使用していたが，機械化連 繶探炭実施とともにカッターの武截能 力，故障の有無が払能率に著し心影響它 与えるだ，高馬力高性能のカッターの 抹用老図り $50 \mathrm{HP}$ ，次いで75 P と逐次切替 えている。これ等の機械上の解決ととも に超合金ビットを研究し、アイコフ製兵 イデイヤピックを使用し，切截能力の增 進とピック取替えその他の死節時党減じ ている。現在硬質の上層炭 $140 \mathrm{~m}$ 岂 3.5 時間で切截しているので，特来更に 200 $\mathrm{m}$ 以上の1方切截も可能である。当所之 しては，塊炭率增加学必要亡する本層に おいてはベンドジブカッター竞，縞炭の 発達した硬質の上羱に対しては，中段切 截のシングルジブ点使用し下荻打上げ危 迠用している。

5. フェースローダー

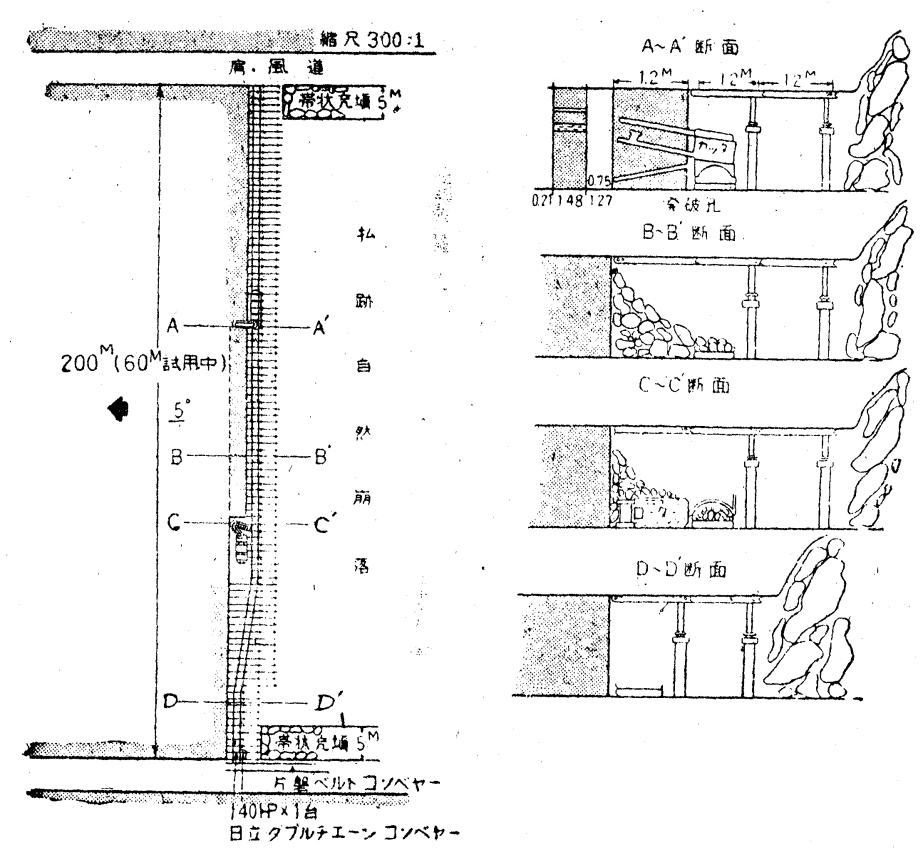

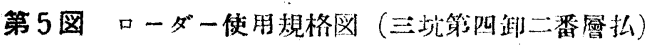

( 38 )
中であり，この型式の探用により完全積込みが解決せら れている。このローダーは下盤上を積込み引続き移設立 杜苍行い肩に到着後、コンぶヤにのせて移動せしめ完全 な連続探炭が可能になつた。当所としてはこれと本行 して連続探炭の可能なプラウ積込みを研究中であるが理 想的な完全積込みの行われるのも遠くないことと思う。 (第5 図参照)

\section{6. 片盤運搬}

払コンぶャの性能向上とともに，片盤運搬能力が要求 
第2表被炭機械故障調査表

昭和 27 年 8 月 昭和 28 年 2 月

\begin{tabular}{|c|c|c|c|c|c|c|c|c|c|c|}
\hline & 部 分 别 別 & 27年/8月 & 月 & 10 & 11月 & 12 & 月 & 28年/1月 & 月 & $\begin{array}{l}7 \text { 年 } / 8 \text { 月 } \\
\text {-28年/2月 } \\
\text { 2年 計 } \\
\end{array}$ \\
\hline ベ & 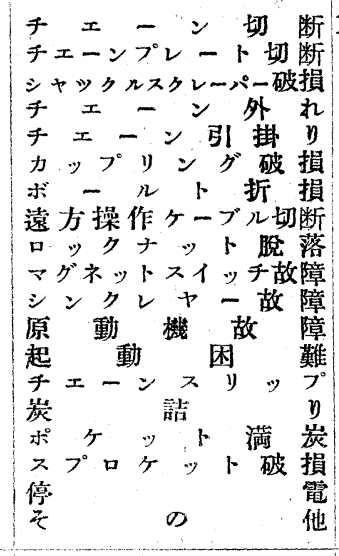 & $\mid \begin{array}{cc}14 \text { 回 } & 10^{\circ} 30^{\prime} \\
1 & 30^{\prime} \\
3 & \\
3 & 1^{\circ} 28^{\prime} \\
1 & \\
1 \text { 回 } & 30^{\prime} \\
3 \text { 回 } & 2^{\circ} 15^{\prime} \\
\text { 1回 } & 2^{\circ} 50^{\prime} \\
5^{\circ} 00^{\prime}\end{array}$ & $\begin{array}{lr}4 \text { 回 } & 3^{\circ} 10^{\prime} \\
1 & \\
1 \text { 回 } & 50^{\prime} \\
\text { 1可 } & 3^{\circ} 40^{\prime} \\
4 \text { 回 } & 5^{\circ} 05^{\prime} \\
1 \text { 回 } & 1^{\circ} 35^{\prime} \\
2 \text { 回 } & 6^{\circ} 15^{\prime}\end{array}$ & \begin{tabular}{cc|}
4 回 & $3^{\circ} 05^{\prime}$ \\
1回 & $55^{\prime}$ \\
& \\
3 & $4^{\circ} 10^{\prime}$ \\
1回 & $30^{\prime}$
\end{tabular} & 1 & $\begin{array}{l}1 \text { 回 } \\
2 \text { 回 } \\
1 \text { 回 } \\
2 \text { 回 }\end{array}$ & $\begin{array}{r}5^{\circ} 00^{\prime} \\
3^{\circ} 15^{\prime} \\
10^{\prime} \\
2^{\circ} 45^{\prime} \\
55^{\prime}\end{array}$ & $\begin{array}{|rr|}7 \text { 回 } 15^{\circ} 20^{\prime} \\
2 \text { 回 } & 1^{\circ} 15^{\prime} \\
& \\
1 \text { 回 } & 10^{\prime} \\
11 \text { 回 } & 2^{\circ} 10^{\prime} \\
3 \text { 回 } & 5^{\circ} 40^{\prime} \\
1 \text { 回 } & 1^{\circ} 20^{\prime} \\
& \\
2 \text { 回 } & 7^{\circ} 20^{\prime} \\
1 \text { 回 } & 40^{\prime}\end{array}$ & 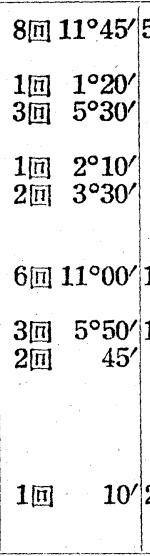 & 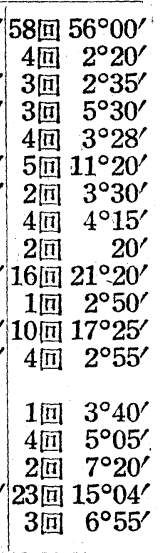 \\
\hline 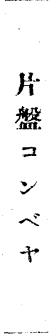 & 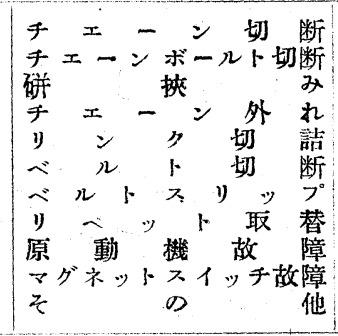 & \begin{tabular}{rr|}
1 回 & $1^{\circ} 00^{\prime}$ \\
2 可 & $1^{\circ} 40^{\prime}$ \\
1 回 & $20^{\prime}$ \\
& \\
3 回 & $3^{\circ} 30^{\prime}$ \\
1 回 & $1^{\circ} 00^{\prime}$ \\
1 回 & $45^{\prime}$ \\
1 回 & $1^{\circ} 10^{\prime}$
\end{tabular} & $\begin{array}{ll}4 \text { 回 } & 2^{\circ} 30^{\prime} \\
2 \text { 回 } & 2^{\circ} 40^{\prime} \\
2 \text { 回 } & 2^{\circ} 05^{\prime}\end{array}$ & \begin{tabular}{cc|}
2 回 & $2^{\circ} 10^{\prime}$ \\
7 回 & $2^{\circ} 30^{\prime}$ \\
1 回 & $20^{\prime}$ \\
2 回 & $1^{\circ} 40^{\prime}$
\end{tabular} & & $\begin{array}{l}2 \text { 回 } \\
1 \text { 回 }\end{array}$ & $\begin{array}{r}5^{\circ} 05^{\prime} \\
35^{\prime}\end{array}$ & \begin{tabular}{ll|}
3 回 & $2^{\circ} 40^{\prime}$ \\
& \\
& \\
1 回 & $15^{\prime}$ \\
1 回 & $20^{\prime}$ \\
& \\
1 1回 & $2^{\circ} 25^{\prime}$
\end{tabular} & 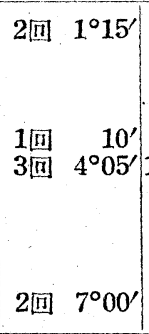 & 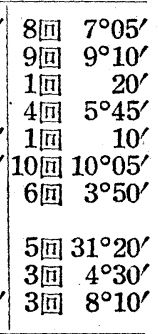 \\
\hline 力 & 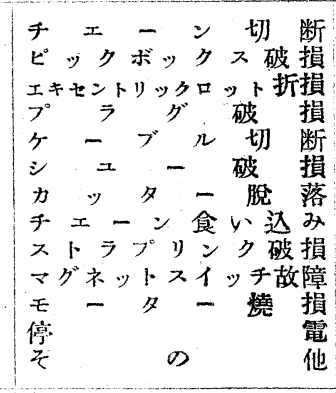 & $\begin{array}{cc}1 \text { 回 } & 1^{\circ} 20^{\prime} \\
\text { 1回 } & 1^{\circ} 05^{\prime} \\
4 \text { 回 } & 6^{\circ} 10^{\prime} \\
& \\
3 \text { 回 } & 2^{\circ} 10^{\prime}\end{array}$ & $\mid \begin{array}{cc}2 \text { 团 } & 3^{\circ} 35^{\prime} \\
2 & \\
\text { 2回 } & 3^{\circ} 00^{\prime} \\
\text { 1回 } & 2^{\circ} 20^{\prime}\end{array}$ & 2回 $8^{\circ} 10^{\prime}$ & & 1回 & $4^{\circ} 50^{\prime}$ & $\begin{array}{l}1 \text { 回 } 5^{\circ} 10^{\prime} \\
2 \text { 回 } 25^{\circ} 50^{\prime} \\
1 \text { 㘣 } 12^{\circ} 00^{\prime} \\
1 \text { 回 } 1^{\circ} 00^{\prime}\end{array}$ & 1 回 $1^{\circ} 10^{\prime}$ & 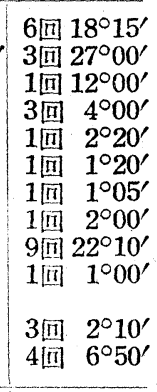 \\
\hline 1 & 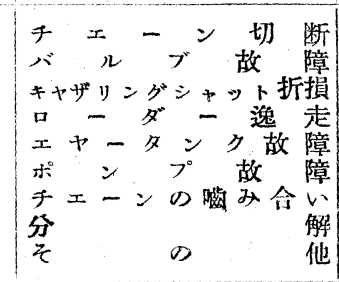 & 2 回 $2^{\circ} 10^{\prime}$ & (1⿴囗十 & & & & & 2 回 $3^{\circ} 10^{\prime}$ & $\begin{array}{ll}2[\text { [i] } & 1^{\circ} 20^{\prime} \\
1 \text { [i门 } & 2^{\circ} 15^{\prime}\end{array}$ & $\left\{\begin{array}{rr}6 \text { 回 } & 6^{\circ} 40^{\prime} \\
& \\
1 \text { 回 } & 40^{\prime} \\
1 \text { 目 } & 2^{\circ} 15^{\prime}\end{array}\right.$ \\
\hline
\end{tabular}

せられ種々の改善が実施せられた。当初は払コンぶヤか らバルト直積が実施せられていたが落口の円滑な運搬

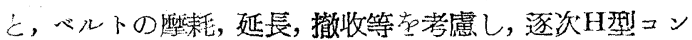
ベヤに切替えている。コンぶヤはH型シングル $500 \mathrm{~mm}$ 巾，出发の多いところで $600 \mathrm{~mm}$ 巾シングルと逐次運搬 能力方向上している。上尿はポケットまでの間孛直接 $\mathrm{H}$ 型コシ心゙ャで運搬し，本層は30〜 50mをH型で運搬し， ベルトコンベャに積込んでいる。ぶルトコンぶヤも従来

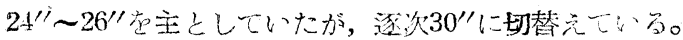

將来自動運転裝置を附し合理化觉図りたい。

\section{7. 使用機器の故障と対策}

上記各種機器の過去牛年間の故障は，第 2 表故障統評 表に示しているが，払コンべヤについてはチェーン切断 が58回の多きに上り，連紿採炭觉漖しく阻害している。 パンッァーについては間題はないが，国産品については 材質の向上之相対的な機構上の解決が要求せられる。こ れに次いでマグネットスイッチ原動機等の電気機器の故 障が多いので早急に解決が要求せられる。片盤コン心゙ヤ 
についてもチェーン及びボルトの切断が多いが，材質强 度の向上が要求せられる。

カッター，ローダーについてもストラップリンク切 断，高馬力の採用によりウォームギャ一等の摩耗が多い が，馬力に応じた穖構上の解決が要求せられる。当所と しては科学的設備管理機構夿一部実行に移し, 各種機器 について点検の基準定定め，故障の早期発見亡適切な姏 置により連続探炭に支障なきよう努めている。

\section{IV 機械化切呵の現況}

当所の䌊傾斜層の條件は次の三つに大別せられる。

1. 比較的軟質厚勫の本尿

2. 硬質厚層の上厤

3. 硬質薄厥の本柾

終戦後輸入，国库の各種機器を導入しこれ等の機器を吕

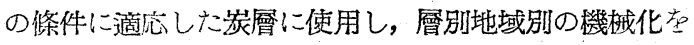
実施す心く努力して来たのであるが，本層炭は軟質であ り，炭質上塊炭率の問題もありピック探炭を，硬質の上 層炭に対してはカッター，ローダー併用の採炭法右実施 し, 能率の向上を図つている。当所の機械化探炭の代表 払として朢抗北部本曆払, 滝一坑四番厤払, 三炕西本片 三番層払について機峨化の現況を述心る。

\section{1. 朢坑北部本層払}

a. 切旸條件並びに規格

面長 $110 \mathrm{~m}$, 傾斜 $10^{\circ}$, 山文 $1.95 \mathrm{~m}$, 炭文 $1.8 \mathrm{~m}$, 地表 下深度 $390 \mathrm{~m}$, 上下岩一砂質頁岩 0.5〜 $1 \mathrm{~m}$ の小断㸴あり。

盤圧 砂質頁岩であり盤生著しい，経常盤圧 25〜30 $\mathrm{t}$, 最大盤圧 $45 \mathrm{t}$ 懸垂し周期的に崩落する。1 日切犲進 行 $1.61 \mathrm{~m}, 1$ 日出炭 $437 \mathrm{t}$, 能率 1 人 1 日当 $6.24 \mathrm{t}$ 。

b. 便用機器

コンぶャー：ウエストフアリャP.F.—1型, 延長 110 $\mathrm{m} 1 \frac{\mathrm{a}}{\mathrm{a}}$

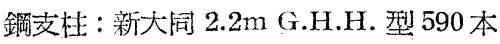

カッヘ：新大同 $1.2 \mathrm{~m}$ 鍛造カッヘ 582 本

片艋コン心゙ヤ，H型シングルチェーンコン心゙ヤ 1 台，心゙ ルトコンぶヤ，26" $26^{\prime \prime} 40 \mathrm{PP} \times 1$ 台, $30^{\prime \prime} \times 40 \mathrm{P} \times 1$ 台, コー

第3表 作業人 員

鋻坑北部第三卸在五片払

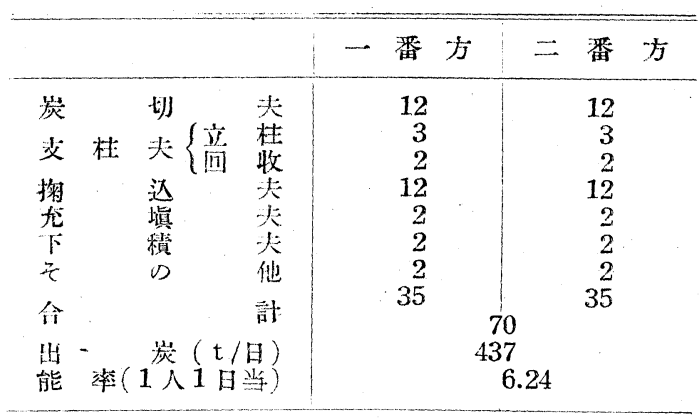

チピック, C.A. $7 \times 24$ 台, 坑木使用量 0.0054 石 $/ \mathrm{t}$

c. 作業人員 70 名編成は第 3 表作業人員表の如し

d. 作業行程

(1) 炭切, カッぺ延長䱊込作業

ピック台数は 10〜12 台，ピック 1 名掬込 1 名 1 組と なり，7〜10 枠 (約6m) 存受持ち探炭を行う。1組当 切付龙量は $14 \mathrm{~m}^{3}$ で約30\%はピック切付とともに自然流 下する。新しい天盤露出とともにカッペ延長を行い, 受 持区域の切付, カッペ延長, 掬込は 4.5 時間要与る。

(2) コンベヤ移設

切付㨨込終了後全員でュンべャを移設し， $5 \mathrm{t} シ ゙ ャ ッ$ キ督使用し移設を補助する。

(3) 立杜回收作業

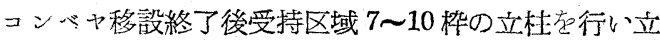
杜時間は 2 名で20分である。回收は 2 組 4 名で立杜終了 後回收可能となつた部分上り逐次回收する。

2. 潼一坑四番愿払

a. 切㹦條件並びに規格

面長 $140 \mathrm{~m}$, 傾斜 $9^{\circ} \sim 10^{\circ}$, 山丈 $1.6 \mathrm{~m}$, 花文 $1.4 \mathrm{~m}$, 地 表下深度 $65 \mathrm{~m}$, 上下盤頁岩, 盤圧 : 上下盤頁岩で後山の 崩落は良いが砂質頁岩の部分は盤圧が高い，経常盤圧20 〜30 $\mathrm{t}$, 最大盤压 $50 \mathrm{t}$ である。

1 日切犲進行 $2.3 \mathrm{~m}, 1$ 日出炭量 $604 \mathrm{t}$ 能率 1 人 1 日 当 $7.36 \mathrm{t}$

b. 使用機器

コールカッター三池 $75 \mathrm{P}$ をシングルジブにて使用 के

フェースローダー：40 H 日立改造 CL-3

コンぶャ：西重H型ダブル趧長 $150 \mathrm{~m} ， 40 \mathrm{P} \times 2$ 台

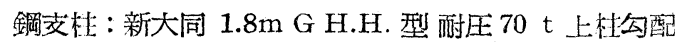
$1 / 120$

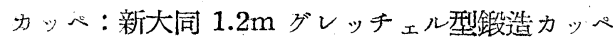

案孔機：NA-65オーガー1台

片盤運搬：H型シングルチェーンコン心゙ヤ20 $\mathrm{P} \times 1$ 台

第4表 作業人員 滰之沢一坑四番層一片払

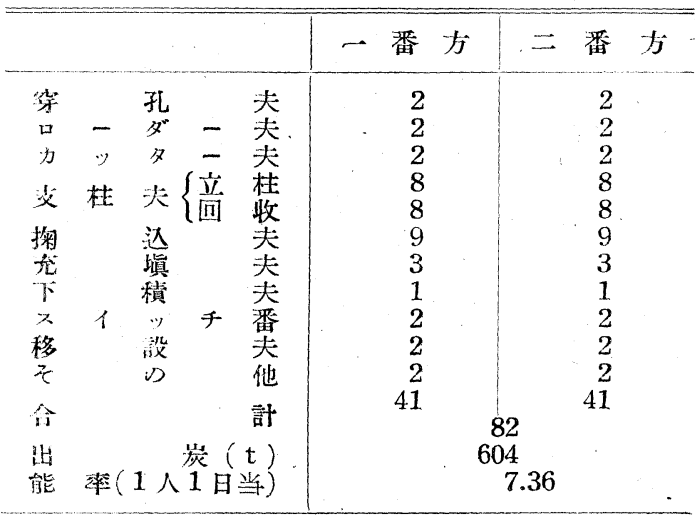




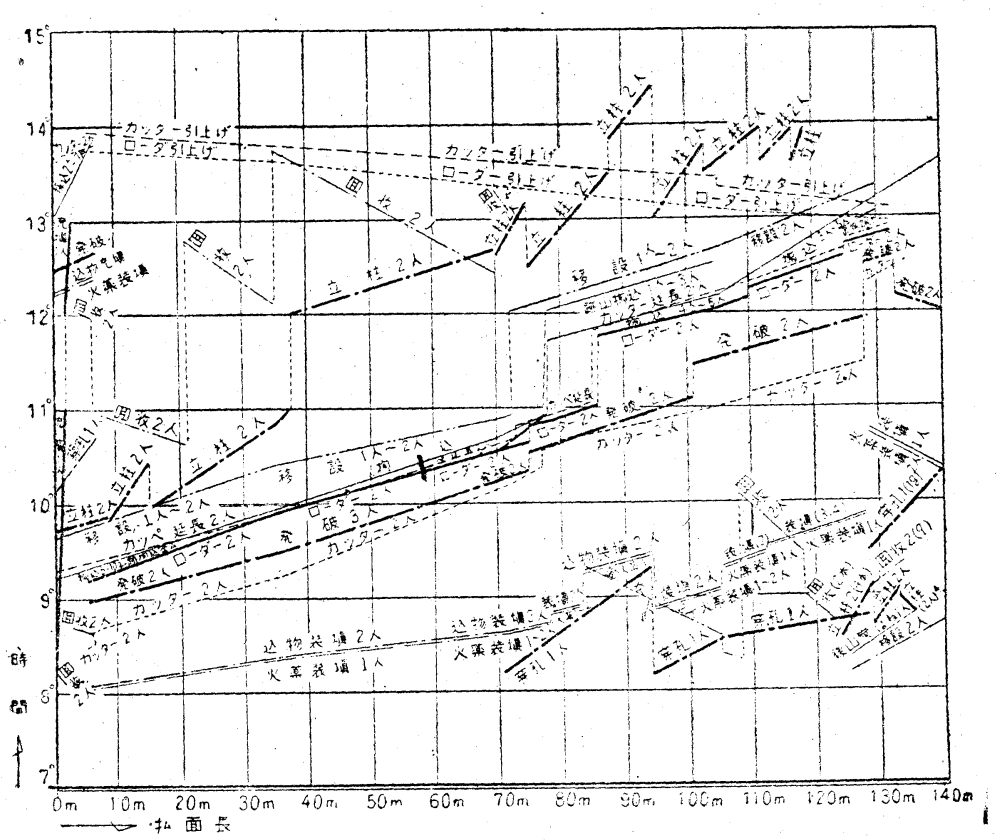

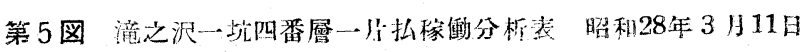

炭の積达を行う掬込夫 8 名

(6) カッペ死長

2 名 1 組, 2 組で発破後カッヘ 延長它行う。

(7) 移設

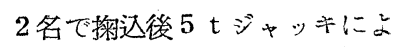
り移設する。

(8) 立杜回收

移設後 2 名 1 組 8 名で $5 \sim 10 \mathrm{~m}$ の距離を置き立杜を行う。立杜終 了部分より安全を見計らつて回收 する。人員は 2 名 1 組 4 名である。 危険な回收には回收器起使用方 る。回收後の鉄杜はボックス不下 とし安全在る。

(9) カッター及びロー

$$
\text { ダー可上 }
$$

積込の終了したローダーはフ ードロープにより引上げる。㫕の 所要時間45分である。カッターは

バルトコン心゙ャ $26^{\prime \prime} \times 2 \mathrm{UP} \times 1$ 厹 $30^{\prime \prime} \times 30 \mathrm{H} \times 2$ 台

c. 作業人員 82 名

作業編成は第 4 表作業人員裴参照

d. 作業工程（第 5 図稼動分析关参照）

穿孔後局よりカッター切下り, 次いで発破, ロー文一 により積込，下炭はね，移設，立杜，回收の順に連続的

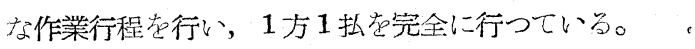
(1) 穿
扎

穿孔夫は 2 名早出を行い，下盤より $60 \mathrm{~cm}$ 及び $30 \mathrm{~cm}$ に干鳥に穿孔し，3.5 時間で案孔を終る。

(2) カッター

三池75Hュールカッター(ウィディヤピック便用)知使 用，下盤より $1.2 \mathrm{~m}$ の位置を肩より切下りを行う。切截 速度は硬質炭であるため 1〜 1.2m/min!で, $130 \mathrm{~m}$ 老 3.5 時間で切截老終る。切截速度は操作を含み $42.5 \mathrm{~m} / \mathrm{hr}$ で ある。

(3) 発破

カッがーより $30 \mathrm{~m}$ の距離在保ち発破克行う。

発破により40\%の石炭はコン心゙ャに流入する。

(4) ローダー

発破後安全な距離を保方, 日立40HP 改造 CL-3 ロダーにより発破後の石炭をコン心゙に積込む。50\%の石 炭は機械積込せられる。積込速度は諸操作学含々56m/br であら。

(5) 掬 込

ローダー積込後コンぶャ高さの残炭と発醊によう飛散
肩抗道のエャー撩とカッターの動力を使用し引上げる。 その所要時間 45 分である。

3. 三坑西本片三番層

a. 切雊条件並びに規格

面長 $100 \mathrm{~m}$, 傾斜 $7^{\circ}$ ，山文 $1.1 \mathrm{~m}$, 地表下深度 $70 \mathrm{~m}$, 上下船：慜緻な頁岩，盤圧 : 盤圧少なく経常盤纴15２0 $\mathrm{t}$, 最大盤圧: $28 \mathrm{t}, 1$ 日切陊進行 $2.08 \mathrm{~m}, 1$ 日出炭量 $221 \mathrm{t}$, 能亲 1 人 1 日当 $5.88 \mathrm{t}$ である。

b. 使用機器

コールカッター：日立 $40 \mathrm{P}$ シングル

フ土ースローダー：40H日立改造 $\mathrm{CL}-3$

フェースコン心゙：自家製H型シングルチェーン30 $\mathrm{PP}$

1 台

鋼交杜：新大同 $1.0 \mathrm{~m} \mathrm{G.H.H}$ 型

カッヘ：新大同 $1.2 \mathrm{~m}$ 異型チャンネル愹接

穿孔機: NA-65 1台

片船運般：ベルトコンベヤ26" $2020 \mathrm{P} 1$ 台

c. 作業人員

38 名, 作業編成は第 5 表作業人員表参照

d. 作業工程

当扗の作業の特徵は $1 \mathrm{~m}$ の薄層におけるカッター，口 一ダー併用の採炭で, 切截, 穿孔, 発破, ローダー, 下炭 は小, 移没, 立杜, 回收の順に連続探炭苍行つている。 薄層であらたわ染量が少ないが，各作業人員特にカッタ - 1 名，ロー多一 1名，その他の作業についても少ない

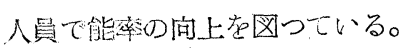

$$
\text { (1) カッター }
$$


第5表 作業人員 三坑西本片三番層厸

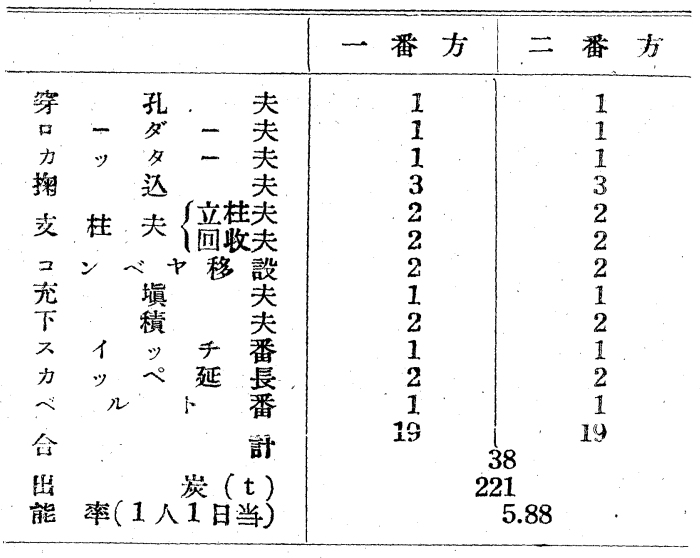

高さの低い日立40世シングルジブを使用し下盤より50 $\mathrm{cm}$ の位置を上问に切截し，上炭を自然流下によりコン 心ヤに崩落せしめている。拆面 $100 \mathrm{~m}$ を 5.5 時間で切截 し可截速度は諸操作を含み $31 \mathrm{~m} / \mathrm{hr}$ である。カッター作 業は1名で行つている。
(2) 穿 孔

カッター切截を追いかけ，下盤祭を穿孔する。

(3) 裝填発破

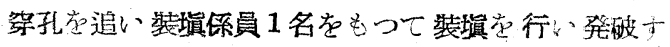

る。

(4) ローダー積込及び掬込

ローダーは1名をもつて運転, 発破後の石炭の積込を 行う。炭量が少ないため $100 \mathrm{~m}$ を 1.2 時間で積込む。 ンふヤ高さの残炭は2名でュンべヤに積込む。

(5) カッへ延長

2 名 1 組で払全面のカッペ延長を行う。

(6) 移 設

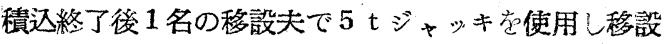
广る。

(7) 立桂回收

䔟設後 2 名在もつて立杜を行い立杜終了後 2 名右もつ 七回收点行方。

\section{V 結言}

以上当所における機械化の推移と成果について述ふた のであるが，現在まだ機械化の途上にあり更に研究を要 †万事が多いが，導入機器を活用し，面長の增加と区域 の集約により合理化の目標を定めこれが完成に遇淮した い上思う。一方使用機器の管理活用に関しては，現在一 部実施中の科学的設備検査制度，並びに職䂗員の機械化

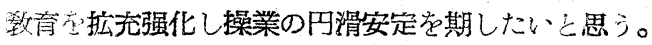

